\title{
The Dog's Tragedy
}

\section{Sylvia Townsend Warner}

In Mitchell County, North Carolina, we had a neighbour, a kind woman who was a Seventh Day Adventist, and the scones she baked were as plump and light as down pillows. She was a big stout woman with eyes like a bull's - small, honest and bewildered. Like a bull she would come charging up through the pasture to our cabin, hurrying to bring us the scones while they were still hot. She was so nice to us that we itched to perform some retaliatory kindness.

Many large women are timid. When she told me that Mr. Macdonald had to go to Tennessee on business I was not surprised to hear her add that she was feeling nervous at the thought of being alone at night. Here was my chance. I would spend the night with her, I said. She demurred a little, said it would be a shame to fetch me out, said her place would not be so comfortable as ours. But I was firm and had my way. That was how I came to see the picture of The Dog's Tragedy.

It hung in a corner of the room, and overnight I did not notice it. The morning sun placed it before my eyes, and its story struck full on my tender early-morning 
consciousness. The bulk of the picture showed a wide and turbulent river, full of cross-currents and boiling eddies. In the foreground was a rock. On the rock was spread out, tidily and thriftily, a toy sailing-boat, a butterfly net, a child's hat, and a child. The child was a little boy, about three years old. He lay so flat it was obvious he was in a fainting condition. It was also obvious that a minute before he had been in the water, for rivulets, scrupulously painted, were trickling from him. (Even before the most story-telling picture, technical considerations will intrude, and though the story of this picture was harrowing to my feelings I had time to think how those rivulets would have rejoiced Ruskin.)

Half in the water, half supported on the rock, was a large black and white Dog, a Newfoundland, or perhaps a Labrador, or perhaps just a trusty cross-breed. He was looking at the sailing-boat, the butterfly net, the hat, and the child, and one could see at a glance that he had just rescued all of them from drowning, being one of those dogs to whom water is a natural element, and brave and kindly acts the commonplaces of an existence selflessly devoted to man. All of this could be read in the dog's countenance, and the way his tongue lolled out showed it had been no easy matter, even for so strong and watery an animal, to drag those four helpless objects from the flood. But there was more in his face than that: there was a look of disillusionment, a growing uneasiness. Plain as print the Dog's face said: 'I've done my duty. But what's gone wrong?'

The rest of the picture made that clear. On the river's farther bank, solitary amid forest and mountain-side, was a log-cabin, and in front of the cabin, holding up her hands in horror, was a woman. There she stood, gazing across at her half-drowned and inaccessible child. For between her and the child flowed the wide turbulent river, and just foundering in mid-stream was a canoe.

Very likely it was her shriek, echoing through the mountain solitude that had first brought it home to the Dog that something had gone wrong. In a minute or two it would all burst upon him: his fatal error in judgment in 
laying a delicate half-drowned child on this comfortless and isolated rock, instead of carrying him back to where his mother could get at him. Then in an agony of regret he would say to himself: 'Damnation! I've gone and done it again. There's no pleasing that woman!' But now the poor darkened, devoted intelligence was travailing with the first suspicion that things weren't so good as he'd meant them to be.

Lying in bed I stared at the picture of The Dog's Tragedy, and tried to pry some mitigating circumstances out of it. Maybe a man would come and do something? But if so the woman would be off fetching him, whereas she stood motionless, the image of despair. No, either she was a widow, or her husband, like Mr. Macdonald, had gone into Tennessee on business.

But the dog was a strong Dog, and the child, though temporarily so limp and damp, probably had a good deal of stamina. After a while the Dog could tow him back again, and fetch, on subsequent journeys, the hat, the butterfly net, and the sailing-boat. So strong and willing an animal would make nothing of a little extra trouble. I looked at the river. It wasn't the sort of river to do a child any good, and another trip through it would be sure to ruin the hat. Even if everything passed off better than one dared hope, even if the child suffered nothing worse than a cold in the head and the hat was an old hat anyway, the Dog would never get more than the poor credit of having retrieved an error.

I could bear it no longer. I got up and began to dress. There were several other pictures in the room, and a magazine with an article about the Dies Committee, saying that the Dies Committee was saving the United States from subversive elements. But I found no comfort. The pictures were just pictures of babies and prize cows and great-uncles, the material for which tragedies were made. For the Dog's tragedy, I said to myself bitterly, is the tragedy of any one of us who tries to do good to others. However courageous we are, however selfless and devoted, and however well we can swim, it's a hundred to one we get it wrong somehow, and land the child on the 
rocks instead of restoring it to its mother. The Dies Committee itself, devotedly saving the United States from subversive elements, will find that it has handed over the United States to something worse.

All day my thoughts were coloured by these gloomy reflections, and at dusk, going for a stroll down the dirt road that led to the main road, I was pensive still. Presently I saw Mr Macdonald driving home and he stopped for a neighbourly word. I asked after the business in Tennessee. He said it had gone all right. Then I said: 'Mrs Macdonald will be pleased to see you back so quick. Last night she felt worried at being alone in the house.' His face cracked open in a smile. 'I guessed she might be feeling that way. Marilda has always been wild to sleep up at your place, but till now she's never got around to it. Marilda, she's got quite a passion for sleeping in other folks' houses.'

Half in the dirt road, half clinging to an imagined rock, I and the Dog kept each other company.

From The Countryman. An Illustrated Review \& Miscellany of Rural Life and Industry. Ed. J.W. Robertson Scott. Vol. XXVI No. 2, Winter 1942, pp.183- 185. 